\title{
DE ULISES AL HIJO PRÓDIGO: UN PROCESO DE SUSTITUCIÓN EN LA LITERATURA MEXICANA HACIA 1920
}

\author{
Juan PASCUAL GAY \\ Colegio de San Luis (San Luis Potosí) \\ jpascualg2011@hotmail.com
}

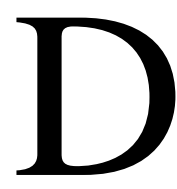
a la impresión de que André Gide, con su obra El regreso del Hijo Pródigo, publicada por Gallimard en 1912, instituye un motivo literario surgido de la nada; como si no hubiera sido un topos particularmente apreciado desde tiempo antes. Más enigmáticas resultan las escasas referencias en su autobiografía, Si la semilla no muere (1927), a esta obra, mientras que sí se detiene en otras como Voyage d'Urien (1893), Les nourritures terrestres (1897) o L'inmoraliste (1902). Por el contrario, en su diario aparecen salpicadas alusiones a El regreso del Hijo Pródigo aquí y allí, pero nunca con la importancia que el autor concede a otras obras. Así, apunta el 8 de mayo de 1911: «A l'imprimerie de Verbeke pour corriger les épreuves de l'Otage, de la Mère et l'Enfant, d'Isabelle, de Corydon et du numéro de juin de la revue» (Gide, 1948: 403). Más explícita resulta una apostilla en uno de los añadidos correspondientes a 1911:

Enfant Prodigue.

Quand il rentre dans la maison qu'il se reproche d'avoir quittée...

Et quand il revoit ce petit jardin don't il se promettait tant de joie, il s'étonne de ne pas trouver les fleurs plus grandes, les fruits plus savoureux et l'affection des siens plus riante (413).

El francés era consciente de que la forma literaria elegida le ofrecía nuevas posibilidades de expresión, como apunta el 14 de enero de 1912: «Avant-hier soir excelente conversation avec Paul Albert Laurens, qui me fait entrevoir la possibilité d'écrire dans un mode tout différent Corydon. Il voudrait que je fasse de cela une oeuvre grave autant que mon Enfant Prodigue; ce qui me donne à réfléchir longuement» (431). En realidad, se trata de una restitución, del rescate de un motivo frecuente en otras épocas. El Hijo Pródigo es un motivo universal que se encuentra tanto en la literatura inglesa del siglo XVII (Snyder, 1966: 361-369) o en la rusa de vanguardia (Hunt, 1982: 24-49), como en las obras maestras de la pintura holandesa de los siglos XVI y XVII (Haeger, 1986: 128-138). Sin duda, la efervescencia y rentabilidad de este motivo en diferentes culturas de occidente se asocia con su origen bíblico, una lección moral en torno a la culpa, el perdón y el amor filial. Las enseñanzas de la 
Biblia no se explican sin la gran difusión de que fue objeto ya desde la Edad Media, considerada indiscutiblemente como auctoritas, presente en todas las actividades del pensamiento humano. Muy pronto la literatura se llena de motivos bíblicos, entre los que no podía faltar el del Hijo Pródigo. De hecho, Alfonso Boix Jovaní es autor del artículo «El perdón del Campeador y el retorno del Hijo Pródigo: ¿la fuente bíblica del Cantar de Mío Cid, vv. 2013-40?» (2010), en el que prueba la presencia del motivo en el Cantar.

El pródigo se asocia con el proceso de secularización iniciado en el siglo XVIII y, una vez atemperado durante el Romanticismo, rehabilitado entre ese laicismo y la teología del momento. Si Gide encontró en el Hijo Pródigo una metáfora de sí mismo, no era ajeno a que igualmente representaba al intelectual moderno. Klaus Mann conjetura acerca de lo que Gide encontró en la parábola:

Esta soberbia pieza de música de cámara es, dentro de sus proporciones menores, la obra más bella y quizás más próxima a la perfección que haya producido nunca Gide. Con traviesa gravedad y solemne gracia, el autor sintetiza todos los temas emocionales de su agitada juventud: su cansancio de la herencia, el éxtasis de su fuga a la libertad, la rebelión contra anticuados convencionalismos y limitaciones, pero también la grandeza y la validez de la herencia, el excitante llamado de lo lejano y no descubierto y nuevamente la legítima fuerza de la jerarquía familiar e indiscutible (Mann, 1944: 109).

Palabras válidas, pero discutibles. El viaje del pródigo es un aprendizaje y un cuestionamiento; una marcha iniciática que polemiza con la identidad del regresado. Imagen de sí y del otro, metáfora de una época y una sensibilidad, pocos podían prever la fuerza con la que irrumpió en la literatura mexicana hasta convertirse en un tema de cohesión y ruptura, acuerdo y debate. Pocas veces un tema hizo tanto por una literatura, y pocas veces también un tema congregó tantas adhesiones y rechazos. Además, el personaje resultaba emblemático de aquellas maneras como Jorge Cuesta y, más tarde, Octavio Paz habían definido la tradición literaria mexicana. Escribía Paz: «De allí que Jorge Cuesta sostenga que el rasgo más notable de nuestra tradición en el "desarraigo". Y es verdad [...] La heterodoxia frente a la tradición castiza española es nuestra única tradición» (Paz, 1994: 35). Desarraigo y disidencia como vocablos operativos no sólo de la tradición literaria mexicana, sino también del grupo de Contemporáneos, como argumentaba Cuesta en el conocido ensayo, «¿Existe una crisis en nuestra literatura de vanguardia?»: «Casi todos, si no puede decirse que son críticos, han adoptado una actitud crítica. Su virtud común ha sido la desconfianza, la incredulidad. Lo primero que se negaron fue la fácil solución de un programa, de un ídolo, de una falsa tradición. Nacieron en crisis y han encontrado su destino en esta crisis: una crisis crítica» (Cuesta, 1994a: 171). Xavier Villaurrutia reconocía la importancia del ejercicio crítico en su desempeño como hombre y escritor, retomando unas palabras de Gide, según ha registrado Miguel Capistrán:

Desde muy temprano, la crítica ejerció en mí una atracción profunda. Confieso que apuraba los libros de crítica con la avidez con que otros espíritus no menos tiernos apuran novelas y libros de aventuras. ¡Nadie pasa impunemente bajo las palmeras de la crítica! Mi castigo, castigo delicioso, no se hizo esperar. El tierno lector de obras de crítica convirtióse bien pronto, a su vez, en crítico.

Más tarde he descubierto que pretender poner en claro los puntos secretos de un texto, intentar destacar las líneas de un movimiento literario y encontrar relaciones y correspondencias en el espacio y en el tiempo entre las obras y los hombres, son, también, pretextos para iluminar, destacar, relacionar, poner a prueba las dimensiones, las cualidades o la falta de cualidades propias (Capistrán, 1994: 199-200). 
La profusión y exuberancia del motivo alineaba a las diferentes facciones no en contra del motivo mismo, sino en relación con su interpretación. Pero ocurrió también que al ser el exponente más visible de determinados grupos, los antagonistas lo volvieron objeto de sus críticas y diatribas sin considerar, en ocasiones, que el Hijo Pródigo, más allá de exégesis y comentarios, representaba la vida de cualquier hombre, como ha documentado Guillermo Sheridan en México en 1932: la polémica nacionalista (Sheridan, 1999: 110-478). El Hijo Pródigo representaba a sí mismo la crítica sustentada por una actitud moral. Un criticismo que se mostraba como consecuencia de una moral cuya verdad no residía tanto en la vitalidad de la obra literaria sino en su cuestionamiento, según argumenta Jorge Cuesta: «Esta actitud no provoca una producción exuberante; no vale, es injusto medirla, por el volumen de su fruto; vale por la actitud misma» (Cuesta, 1996a: 171-172). En otro lado, es el mismo Gide quien establece, en una conferencia cuyos fragmentos se publicaron por primera vez en L'Art Moderne en abril de 1900, una distinción operativa a la hora de hablar de diferentes tipos de influencias:

Así pues, existen dos clases de influencias, las influencias comunes y las influencias particulares; aquellas que toda una familia, una agrupación de hombres o un país experimentan al mismo tiempo; y aquellas que nada más uno experimenta en la propia familia, en la propia ciudad y en el propio país (voluntariamente o no, consciente o inconscientemente, que uno mismo ha elegido o que lo han elegido a uno). Las primeras tienden a reducir al individuo al tipo común; las segundas, a oponer al individuo a la comunidad (Gide, 2007: 19).

Sin titubear, como asienta líneas después el propio autor, las decisivas son las «influencias particulares». La idea de la influencia particular delata ese trato preferente y vecinal entre escritores de una misma edad, sobre todo en su juventud, y, en todo caso, salvaguarda la asimilación de esa presencia en cada autor. Pero tampoco quiere decir que esa influencia -la de un autor, un artista, una novela, un poema, etcétera- no polemice entre quienes han sido seducidos por ella.

Entender la complejidad que encierra el Hijo Pródigo lleva inevitablemente al clasicismo francés. Paul Bénichou suscribe, en Imágenes del hombre en el clasicismo francés, unas palabras que ayudan a entender la vehemencia con la que el romanticismo primero y, más tarde, la modernidad adoptaron el motivo bíblico como una representación de sí mismos: «El cristianismo optimista, por el contrario, unía el orden natural con el orden divino por una gama ascendente y continua de perfecciones. Sin duda el dogma imponía planos distintos: el de la gracia, el de la naturaleza excelente, virtud y conocimiento, el de la naturaleza bruta; dicho de otro modo: Dios, el Edén, el hombre tras la caída. Dos fosos habían de abrirse, el uno entre la concupiscencia y el bien, el otro entre el bien y la caridad» (Bénichou, 1984: 93). Las consecuencias de estas palabras fueron decisivas para una nueva moral surgida de la convicción de que la dignidad del hombre únicamente puede sentirse si antes se aceptan sus miserias. Entre estos dos extremos cabe situar la relevancia del Hijo Pródigo que se instala en una dialéctica que se debate entre la grandeza que deviene miseria y una miseria que desemboca en grandeza. El Hijo Pródigo es portador del significado del arrepentimiento, pero también de la rebeldía; de la curiosidad y la aventura, pero también del perdón. Rebeldía y curiosidad expresan el sentido de la modernidad; obediencia y perdón se apegan a la tradición. En México, a finales de la segunda década 
del siglo XX, el Hijo Pródigo olvida su origen, se emancipa definitivamente como asunto literario relegando su origen evangélico.

El Hijo Pródigo nace de una de las parábolas del evangelio. El único evangelista, paradójicamente uno de los sinópticos, que registra esta parábola es Lucas XV: 11-32. José Emilio Pacheco erróneamente le atribuye a Juan la parábola, en el prólogo a la edición de 1991 de El regreso del Hijo Pródigo de la editorial Fontamara, al decir que «esta es la parábola más célebre del mundo cristiano. A diferencia de otras mediante las cuales habló Jesucristo ("Porque viendo no ven y oyendo no oyen”) aparece exclusivamente en el evangelio de San Juan» (Pachecho, 1991: 9). El mismo Gide, al comienzo de su texto traducido por Xavier Villaurrutia, El regreso del Hijo Pródigo, remite a la parábola:

He pintado aquí para mi alegría secreta, al modo de los antiguos trípticos, la parábola que contó nuestro señor Jesucristo. Dejando dispersa y confundida la doble inspiración que me anima, no intento probar la victoria de ningún dios sobre mí -ni la mía. Tal vez si el lector exige alguna piedad de mí, no la buscará en vano en mi pintura donde, como un donador en el ángulo del cuadro, me he puesto de rodillas, en simetría con el Hijo Pródigo, como él sonriente y con el rostro surcado de lágrimas (Gide, 2003: 7-8).

Pero el pródigo no es únicamente la expresión del perdón, sino también una alegoría de la vida como viaje. Es justamente San Pablo quien, en Hebreos XI: 8-16, consigna que Abraham vivió en la tierra prometida como extranjero:

Por la fe Abraham, al ser llamado, obedeció y salió hacia la tierra que había de recibir en herencia, pero sin saber adónde iba. Por la fe moró en la tierra de sus promesas como en tierra extraña, habitando en tiendas, lo mismo que Isaac y Jacob, coherederos de la misma promesa. Porque esperaba él ciudad asentada sobre firmes cimientos, cuyo arquitecto y constructor sería Dios. Por la fe la misma Sara recibió el vigor, principio de una descendencia, y esto fuera ya de la edad propicia, por cuanto creyó que era fiel el que se lo había prometido. Y por eso de uno, y éste ya sin vigor para engendrar, nacieron hijos numerosos como las estrellas del cielo y como las arenas incontables que hay en las riberas del mar.

Ambos pasajes invitaban a considerar un cristianismo de manera radical, mediante el que el hombre se asume como un exiliado hospedado en tierra extraña aun cuando fuera la suya, comprometido con la búsqueda de una ciudad mejor lejos en donde construir la verdadera patria. M.

H. Abrams refiere que

La vida cristiana modelo, ya sea individual o genérica, prosigue un curso de aquí allá que tiene sus puntos altos y bajos, sus catástrofes e inversiones, pero apunta hacia una meta que, aunque es un derecho de nacimiento, es un lugar diferente y más elevado que aquel de donde partió. Este tropo central de la vida como peregrinación atrajo a su órbita a varias historias del Antiguo Testamento sobre exiliados errantes, especialmente el relato del éxodo del pueblo elegido huyendo de su esclavitud en Egipto y de sus prolongadas errancias en las regiones salvajes antes de su entrada en la tierra prometida (Abrams, 1992: 163).

Tanto los versículos de Hebreos como los de Lucas proponen en primera instancia la vida como un viaje lineal, como una peregrinatio a la búsqueda de la perfección, como una vía ascética. Esa peregrinatio como vía de conocimiento y camino de perfección interior es medular desde el comienzo de El viaje de Urién. Se trata de una obra iniciática, primeriza, pero que en su deslumbrante simbolismo ofrece ya aquellas directrices que más tarde, de manera pausada y madura, el autor dota de mayor complejidad. Con todo, hay que observar que ese viaje a ninguna parte emprendido por Urién es 
igualmente una apología del viaje inmóvil literaturizado por Xavier de Maistre en Voyage autour de ma chambre, en 1794, y tan redituable en términos literarios para algunos cenáculos como los Contemporáneos de México, sólo hay que pensar, por ejemplo, en los sonetos que integran «Viaje inmóvil» de Jaime Torres Bodet o en el poema «Nocturno de la inmovilidad y del olvido» de Enrique González Rojo. No hay que olvidar ese ensayo de Gabriel Fernández Ledesma, cuyo título traduce literalmente del francés, Viaje alrededor de mi Cuarto, publicado en 1958, pero que recrea una estancia del autor en París en 1938. José Gorostiza prefiere a Lao-Tse, de quien recupera este proverbio: «Sin traspasar uno sus puertas, se puede conocer el mundo todo; sin mirar afuera de la ventana, se puede ver el camino del cielo. Mientras más se viaja, puede saberse menos. Pues sucede que sin moverse, conocerás; sin mirar, verás; sin hacer, creará» (Gorostiza, 1988: 68). Este pensamiento le lleva a establecer una estrecha relación con la poesía como apunta a continuación: «He aquí descrita, en unas cuantas prudentes palabras, la fuerza del espíritu humano que, inmóvil, crucificado a su profundo aislamiento, puede amasar tesoros de sabiduría y trazarse caminos de salvación. Uno de estos caminos es la poesía. Gracias a ella, podemos crear sin hacer; permanecer en casa y, sin embargo viajar» (69). Guillermo Sheridan, en Los Contemporáneos ayer, comenta que el interés por «el viaje inmóvil» para los miembros del Ateneo de la Juventud tuvo su origen en la lectura que Xavier Villaurrutia hizo de un texto del español Juan Chabás (Sheridan, 1985: 222). Una afirmación más que discutible si se atiende a las fechas. Es significativa, en todo caso, la reseña de Villaurrutia entregada a las páginas de Contemporáneos, en agosto de 1928, «Juan Chabás y el pudor», a propósito de la novela del español, Puerto de Sonilva. Los aspectos que destaca Villaurrutia son precisamente los asociados con la inmovilidad y el sueño a los que dedica una morosidad premeditada alentada por el recuerdo:

Al borde del mar, sentado en una mecedora, con los pies sobre un pequeño escabel, Adolfo Aprile cierra los ojos y, luego, muy despacio, palpa con los dedos los párpados caídos. La presión de los dedos sobre la tela de los párpados hace surgir el recuerdo. Adolfo Aprile se sumerge con la misma lentitud que usamos, nadadores, en los tanques o, durmientes, en los sueños. En esa sumersión, los segundos se alargan con la misma blandura lenta con que estiramos una cinta elástica o, de otro modo, como el salto de un caballo detenido por fotografías rapidísimas y que luego, traducido a la pantalla, nos da una sensación untuosa y lenta hasta el ahogo. Adolfo Caprile desciende. Y esta sumersión que Juan Chabás recoge saboreando su lentitud en más de cien páginas, ha durado solamente el tiempo de un cerrar y abrir de ojos (Villaurrutia, 1928: 334-335).

En realidad, la curiosidad por el viaje inmóvil ya estaba presente por lo menos desde 1919 entre los jóvenes escritores y, en todo caso, la lectura de Chabás vino a enfatizar esa elección primera. Además, hay que recordar la obra de Eugenio d'Ors, Oceanografía del tedio. Historias de las Esparragueras, publicado en 1921, una vehemente apología del tedio entendido de manera estricta.

Gide en su primera obra había hecho del viaje un asunto central, pero más que de un viaje se trataba de una errancia, un itinerario sin regreso ni propósito, una evasión y una huida, impulsada por la abdicación de unos jóvenes de sus estudios teológicos en favor de la acción. Así lo consigna el autor en el prefacio a la segunda edición:

Ignoran [los jóvenes] su destino y no gobiernan su navío, pero un deseo de voluntad los engaña y los hace confundir con un rumbo resuelto el que seguirá la azarosa nave. Ante todas las voluptuosidades, no se 
privan por recompensas futuras que no las satisfarían, sino por acciones gloriosas que pongan a prueba su fuerza y la conserven entera. Puede que estén locos... por eso, no digo que sean sabios. De lo que más sufrirían sería de carecer de una lucha a la que lanzarse, de conquistas por lograr. Aun en ese caso no dirían que su abstinencia era vana, pues llevan la fuerza dentro; podrían conquistar. Tal vez sea tentar a Dios... pero compensa su orgullo... (Gide, 2003: 118).

La escritura de esa iniciación siempre pendiente del futuro a costa de relegar el pasado, habría de convertirse en una referencia obligada para sus obras posteriores y para sus lectores. Octavio Paz, en el artículo «Contemporáneos», registraba tanto el interés de Jorge Cuesta como el suyo por André Gide precisamente por su magisterio en lo concerniente a la curiosidad y la acción: «Era la primera vez que yo comía en un lugar elegante iy con Jorge Cuesta! Hablamos de Lawrence y de Huxley, es decir de la pasión y de la razón, de Gide y Malraux, es decir, de la curiosidad y la acción» (Paz, 1994: 72).

Sin embargo, hay que preguntarse por qué fueron precisamente los exégetas neoplatónicos quienes sintieron antes una fascinación indisimulable hacia el Hijo Pródigo, que no renunciaba a esa accesis, pero ofrecía otra lectura igualmente ajustada al texto. La historia no era lineal, sino circular, puesto que para que el hijo pudiera pedir perdón debía regresar al hogar del padre. Pero esa vuelta no bastaba en sí misma, tampoco el arrepentimiento filial, sino el reconocimiento del hijo por parte del Padre. Así, la parábola se apegaba al principio de la tragedia clásica que reside en la anagnórisis, es decir, en el reconocimiento del retornado. En pocas palabras, la parábola relata la historia de un hijo que le pidió al Padre la parte que le correspondía de la herencia y «partió a una tierra lejana, y allí disipó toda su hacienda viviendo disolutamente». Una vez que la malgastó, se puso a servir a un porquero, y allí, entre los cerdos, «volviendo en sí, dijo: ¡Cuántos jornaleros de mi padre tienen pan en abundancia, y yo aquí me muero de hambre! Me levantaré e iré a mi padre y le diré: Padre he pecado contra el cielo y contra ti». El hijo no tuvo que entrar en la morada del padre, sino que esto lo vio a lo lejos, lo reconoció y corrió a abrazarlo, después de lo que ordenó una fiesta hacia la que el hermano mayor, el primogénito, mostró su rechazo, mientras el padre responde al reclamo filial: «Hijo, tú estás siempre conmigo y todos mis bienes tuyos son; mas era preciso hacer fiesta y alegrarse, porque este tu hermano estaba muerto y ha vuelto a la vida, se había perdido y ha sido hallado». Hay algo que roza lo calvinista o, por lo menos, una ortodoxia extrema. André Gide, como reconoce en su autobiografía, había leído en su adolescencia a «Bossuet, Fénelon, Pascal» (Gide, 2002: 164), habiendo recibido una formación puritana que lo condicionó tanto en sus gustos como en sus decisiones. La estricta moral en la que fue educado lo llevó a integrar lo mejor del romanticismo en el clasicismo, lo cual ex plica su curiosidad e interés por las figuras bíblicas.

El moralismo de Gide exigía además una responsabilidad sin la que hubiera sido desacreditado, según esas palabras de Julien Benda recogidas por Olivier Todd:

Considero que el escritor que trata de posiciones morales, no al modo objetivo del historiador o del psicólogo, es decir, señalándolas con juicio de valor -y es exactamente el caso del autor de las Nourritures terrestres, de Numquid et tu y de muchas páginas de su diario-, tiene el deber de adoptar una posición clara, so pena de caer en la predicación del diletantismo, la cual constituye, especialmente en materia moral, una insigne traición de intelectual (cit. en Todd, 2002: 68). 
Alfonso Reyes comentaba en una colaboración para la revista Contemporáneos, en septiembreoctubre de 1930, la diferencia entre Gide y Benda a la hora de entender la literatura:

Hay, en Francia, escritores que se preocupan del diálogo o disputación entre la Moral y la Inteligencia. Unos caen de un lado -y se complacen, como André Gide, en las sorpresas con que la realidad desordena los cuadros de deberes o las previsiones de la filosofía y la ciencia admitidas; y otros caen del otro -y más bien procuran reorganizar, crear un orden, nuevo o viejo, poner los puntos sobre las íes.

Entre los que ponen los puntos sobre las íes, andan mezclados varios hermanos enemigos: el grupo de L'Action Francaise, los monarquistas Maurras, Daudet y Bainville, por ejemplo, todos los días tienen cuestiones con el francotirador del orden Julien Benda. Y es que usan lenguaje parecido y, en el fondo, se disputan el mismo ministerio de almas (Reyes, 1930: 181-182).

Quizás por eso, para Benda, la estética de Gide le resultaba indiferente y la propuesta de la Nouvelle Revue Francaise no era más que el estéril triunfo de la literatura por la literatura.

Louis Panabière justifica el interés de los Contemporáneos por lo que se ha dado en llamar el «Neoclasicismo» francés: «Para entenderlos, debemos interrogarnos sobre el objeto preciso de su admiración y preguntarnos a qué deseo responde. Lo que provoca en primer lugar el entusiasmo de los Contemporáneos por el Neoclasicismo es el reconocimiento de un acuerdo creador entre la pasión y el rigor del ejercicio espiritual: “¡Milagroso acuerdo del 'ascetismo’ poético con 'la ciencia francesa del placer!"” (Panabière, 1983: 226-227). Pronto asume Gide su protestantismo, según consigna en Si la semilla no muere, como principio diferencial con sus compañeros de estudios en el Liceo de Montpellier, donde ingresa a la edad de doce años: «La clase y todo el liceo se dividía en dos facciones: estaba el partido de los católicos y el partido de los protestantes. Cuando entré en la École Alsacienne me había enterado de que yo era protestante» (Gide, 2002: 102). Pero particularmente significativas son las líneas siguientes: «Mi educación puritana me había convertido en un monstruo a las reivindicaciones de la carne. ¿Cómo podía comprender en aquel tiempo que mi naturaleza eludía la solución más generalmente admitida tanto como la reprobaba mi puritanismo?» (232). El puritanismo causó una profunda escisión respecto de la homosexualidad del francés. El padecimiento debido al enfrentamiento entre sus principios morales y sus impulsos naturales cobra dramatismo en las páginas finales de su autobiografía, en las que admite que «me hubiera gustado conciliar los puntos de vista más diversos sin excluir nada y dispuesto a confiar a Cristo la solución del litigio entre Dionisos y Apolo» (338); un sentimiento que explica de alguna manera la lectura y reescritura del Hijo Pródigo a la que procede. Esa necesidad de conciliar los contrarios es justamente la que expone Antonio Caso en su colaboración «La moralidad del arte», aparecida en el número 8, el 29 de junio de 1917, en $E l$ Universal Ilustrado:

La ley fundamental del pensamiento es el principio de contradicción, que dice: una cosa no puede ser y dejar de ser al mismo tiempo. Si, pues, se logra demostrar que toda obra de arte verdadera consiste en la intuición o expresión desinteresada de la realidad individual, ninguna obra de arte será inmoral, porque precisamente es inmoral obrar o pensar interesadamente, y nada puede ser y no ser al mismo tiempo, conforme al principio de contradicción; por consiguiente, la obra de arte, cuya esencia es el desinterés, nunca podrá mover el interés, es decir, nunca será inmoral (Caso, 1917c: s. p.).

Es ejemplar el final de Si la semilla no muere, en el que Gide denuncia a las diferentes iglesias por haberse apropiado de la interpretación de las Sagradas Escrituras: 
[...] cómo y con qué arrebatos de amor pude volver a encontrar el Evangelio, ni tampoco la enseñanza que saqué de él cuando, al leerlo con ojos nuevos, vi que iluminaban de pronto su espíritu y su letra. Y me desconsolaba e indignaba a la vez lo que habían hecho las Iglesias con esa enseñanza divina, pues era muy poco lo que reconocía de ella a través de aquéllas. Me repetía que nuestro mundo occidental perecía por no haber sabido verla en él o no haber consentido en verla en él; tal llegó a ser mi convicción profunda, así como la de que me incumbía el deber de denunciar ese mal. Pensé, pues, en escribir un libro que mentalmente titulaba Le Christianisme contre le Christ, libro muchas de cuyas páginas están escritas y que sin duda habría aparecido ya en épocas más tranquilas y sin ese temor que puedo sentir, si lo publicase enseguida, de contristar a algunos amigos y de comprometer gravemente una libertad de pensamiento a la que atribuyo más valor que a todo lo demás (Gide, 2002: 339).

Y eso, en parte, es lo que parece probar la parábola del Hijo Pródigo: pobre, solo, desamparado, sin presente y futuro, decide volver con su padre. Ahora bien, ¿verdaderamente el arrepentimiento fue auténtico o, por el contrario, se trató de una decisión meramente racional dadas las circunstancias? $¿$ ¿No exagera el padre al atribuir a su hijo un arrepentimiento que estaba por demostrar? ¿No se precipita el padre en su perdón? Desde el punto de vista teológico, no hay duda del sentido del pasaje, pero ¿desde el punto de vista del lector que carece de fe? ¿Acaso no hay demasiados cabos sueltos que invitan a reinventar la parábola, que se ofrecen para reescribir la historia? Es clara la actitud del padre, pero la ambigüedad del hijo suscita demasiados interrogantes. Precisamente este equívoco permite entender la modernidad de la parábola o quizás comprender la fascinación que ejerció en tantos intelectuales al margen de la fe y la religión. En estos casos, la razón abdica a favor de la intuición, que si no demuestra, ofrece al menos respuestas personales o añade más preguntas a esos mismos interrogantes. El Romanticismo retoma esta cesura de la certidumbre asociada a la razón, para proponer un viaje personal e intransferible. Un desplazamiento semejante al del Hijo Pródigo de quien al principio de la parábola se ignoraba su destino. La errancia abre su propio camino. Pero errar no es necesariamente viajar, puesto que tanto el errante como el vagabundo ignoran el propósito de su camino, a diferencia del viajero, cuyo propósito incita el viaje mismo. Distinto es si llega a la meta formulada en el principio del camino, no así el vagabundo o vagamundo que camina sin sentido ni intención, desplazándose a través de caminos que no son caminos puesto que su errar carece de principio y fin. El viajero sabe adónde va, conoce el fin del camino, su objeto y su propósito; en esto se parece al nómada que recorre caminos en donde aparentemente no existen, pero no necesita que existan para recorrerlos. El Hijo Pródigo es también la imagen del hombre en busca del conocimiento. La marcha del Hijo Pródigo es una partida hacia ninguna parte, es el vagar de quien no tiene casa; en su impenitente deambular no hay otra intención que gastar la parte de la herencia; el camino no es ya un medio, sino un fin en sí mismo. Únicamente la mendicidad dota de sentido y fin su regreso, la morada paterna. El retorno es el desplazamiento significativo del pródigo. San Agustín, en opinión de Roy Battenhouse (1955: 15), estructura las Confesiones de acuerdo a la parábola del Hijo Pródigo, al recordar que el de Hipona había escrito: «No es con los pies ni con los intervalos de lugar como se aleja uno de ti o como se vuelve a ti. ¿Buscó, acaso, aquel tu hijo menor, caballos o carros o naves, o voló con alas visibles, o recorrió el camino moviendo las piernas para derrochar pródigamente, viviendo en región lejana, lo que tú le habías dado, Padre dulce cuando se lo dabas al partir y más 
dulce cuando volvía menesteroso?» (I, XVIII). Pero desde la perspectiva neoplatónica, acaso sea más relevante el siguiente pasaje también de las Confesiones: «Por la continencia, en efecto, nos recogemos y reducimos a la unidad, que habíamos perdido derramándonos en lo múltiple» (X, XXIX). La continencia se repliega en la unidad, la incontinencia se abisma en la dispersión de la persona. En otras líneas, San Agustín afirma la disgregación a la que lleva la falta de continencia que separa al hombre de la unidad de Dios y disgrega al hombre mismo en su interior: «Así es como fornica el alma cuando de ti se aparta y busca fuera de ti lo que no encuentra puro y límpido más que cuando torna a ti» (II, VI). La vuelta del hijo a la casa del padre es también una alegoría del regreso de la parte al todo. Por ello, Abrams concluye que «Gracias a una fusión de la peregrinación de la Epístola de los Hebreros, el viaje circular del Hijo Pródigo, la culminación del Libro de la Revelación y la imaginería del Cantar de los Cantares, la meta del complejo viaje es a la vez un país y una ciudad y un hogar, a la vez un lugar y una persona, a la vez masculina y femenina, y un padre que es también la madre» (Abrams, 1992: 164). Esta complejidad de la parábola no se le escapó a la Gide, ya que venía a compendiar todo aquello que el hombre es capaz de sentir y vivir a lo largo de su vida.

Pero la parábola del Hijo Pródigo es también la alegoría del bautismo o un segundo nacimiento, comparable en el Antiguo Testamento al pasaje en el que Abraham se decide a sacrificar a su hijo Isaac, pero Dios le detiene la mano en el momento mismo de degollarlo. Se trata de un pasaje que, como indica J. G. Frazer, además del segundo nacimiento, remite a la sustitución del lugar del hijo mayor por el menor, es decir, del cambio de la primogenitura:

El hermano menor se hizo pasar por el otro con ayuda de la estratagema consistente en vestirse con sus ropas y en cubrirse las manos y el cuello con pieles de cabrito, con el fin de imitar la extraordinaria vellosidad del hermano mayor; y a ese acto le indujo su madre, que tomó parte activa en él ayudando al hijo a ponerse las ropas del otro hermano y a cubrirse manos y cuello con las pieles. De esa manera consiguió Jacob, el hijo más joven, atraer sobre sí la bendición paterna que estaba destinada al hermano mayor y ocupar en su lugar el puesto de heredero de los bienes familiares (Frazer, 1981: 274).

No menor es el tema del viaje asociado con el Hijo Pródigo como ya ha quedado consignado en las Confesiones, pero también representado de manera paradigmática en la Divina Comedia, en concreto, en el verso inicial del Canto Primero: «A la mitad del camino de nuestra vida» (Alighieri, 2011: 95), en el que asocia la autobiografía espiritual del italiano con la alegoría genérica, pues Dante es a la vez individuo y peregrino cristiano que una vez que ha descendido a los infiernos, asciende al paraíso, previa estancia en el purgatorio. El viaje es asunto central desde Homero hasta Dante, pero también resulta algo más que significativo en relación con el Hijo Pródigo.

Por otro lado, conviene retomar el pensamiento neoplatónico tan próximo a los exégetas de la parábola. En particular, hay que mencionar a Plotino no sólo por su presencia en el pensamiento agustiniano, sino también por su importancia en las reflexiones de José Vasconcelos. El plotinismo del mexicano permite entender la acogida de la parábola del Hijo Pródigo aunque esta llegara a través de la obra de Gide a partir de los años veinte y, además, se asocia igualmente con el viaje. En la introducción a El monismo estético (1918), Vasconcelos trazaba el fondo moral del conocimiento o, como sentencia, «el misterio del juicio estético» opuesto a las filosofías inspiradas en la razón pura y 
en la razón práctica (Vasconcelos, 1961: 16). Pero más allá de esa moralidad, asentaba la necesidad de volver a una directriz unitaria, a una forma que compendiara todas las demás, capaz de unificar «las tres formas de actividad, la intelectual, la moral y la estética, en el pathos especial de la belleza» (16), propósito del que da cuenta cabal el título mismo del ensayo. Así, el verdadero arte es aquel que es capaz de desvelar, alumbrar, exhibir la unidad esencial entre la heterogeneidad aparente de los seres:

El verdadero arte dista inmensamente de todo esto. El arte que puede ilustrarnos es todo arranque antirrealista, más allá del instinto y más allá de la razón; el arte que nos levanta por encima de la tierra en el Phedro platónico; el arte olímpico de Fidias; no el bajo de la Venus de Milo y la decadencia de Praxíteles; el arte de Esquilo y de Eurípides, del Dante y de la música clásica; todo el gran arte: un arte constantemente sacudido por el calosfrío misterioso de lo sublime y siempre sobresaltado por el descubrimiento, de que habla Kant, de una unidad interna entre las series heterogéneas de los sucesos y los fenómenos; unidad no lógica sino de destino y de síntesis en el ser infinito (20).

La curiosidad a la hora de indagar en la relación entre misticismo y arte es la que, en opinión de Claude Fell, condiciona la fuente plotiniana del pensamiento vasconcelista: «Lo que primero descubrió en Plotino fue que la preocupación por vida espiritual y la purificación del alma debía tener prioridad por sobre la adquisición de una cultura intelectual propiamente dicha. Plotino "repiensa" el platonismo para ponerlo al servicio del perfeccionamiento del alma; además, fue uno de los primeros que intentaron establecer conexiones entre el pensamiento "occidental" y los filósofos orientales; por último, más que maestro anhelaba ser "un guía espiritual”, y buscaba en sus oyentes una adhesión más pasional que racional» (Fell, 1989: 376). Por eso no resulta en absoluto chocante que uno de los autores seleccionados dentro de los libros verdes ${ }^{1}$ fuera precisamente el de las Enéadas, en cuyas páginas no es difícil rastrear la lectura que interesó a José Vasconcelos, sobre todo las páginas relacionadas con las virtudes contemplativas como medio para alcanzar la semejanza con Dios, el Uno según Plotino: «Las virtudes cívicas, moderando nuestras pasiones, se proponen enseñarnos a vivir conforme a las leyes de la naturaleza humana. Las virtudes contemplativas arrancan las pasiones del alma, se proponen hacer al hombre semejante a Dios. Una cosa es purificarse y otra ser puro. Las virtudes purificativas pueden considerarse como la purificación misma desde dos puntos de vista: unas y otras purifican el alma y la adornan porque el objeto de la purificación es la pureza» (I, 2, 1). Vasconcelos proponía así una relación indivisible entre moral y estética. Esta indivisibilidad que en el caso de los ateneístas se vuelve central puesto que condiciona la contemplación estética a la perfección del sujeto que la contempla, no sólo rehabilitaba las premisas del nuevo intelectual surgido de las cenizas a las que los decadentistas habían reducido esa ejemplaridad, sino que proponía nuevos caminos para transformarla en una disidencia como sucedió, poco después, con los Contemporáneos. Con todo, conviene insistir que estas convicciones vasconcelistas fueron asumidas por el resto de integrantes del Ateneo, como se colige de las siguientes palabras de Samuel Ramos incluidas en la revista $L a$ Antorcha, en 1925: «para llegar a la contemplación de lo Bello, es preciso que antes se haga bello el sujeto contemplador» (19). Pero Fell va más allá al afirmar que «Vasconcelos conservará y desarrollará

\footnotetext{
${ }^{1}$ Así se conoció a los volúmenes que integraron la colección Clásicos Universales lanzada por José Vasconcelos como Secretario de Educación, puesto que las tapas son de ese color.
} 
esta doble idea de la fusión necesaria de la ética y de la estética, y del papel de intermediario privilegiado que es el del artista en la senda de lo Bello y, más allá, del Bien» (Fell, 1989: 376-377). Vasconcelos traspasa los límites que el propio Caso en «La moralidad del arte» había impuesto a la hora de explicar la relación entre el artista y su objeto:

El artista, según lo han descrito Schopenhauer y Bergson, tiene un desinterés innato de la mente que lo faculta para intuir o contemplar cada cosa o ser en su individualidad característica; por eso, en un rebaño, sabrá, como el Buen Pastor, cuál es una oveja entre las demás ovejas; cuál el carnerillo singular que para los demás hombres, es tan trivial como los otros carneros. El artista pone su desinterés en la obra de arte. Hace de la obra el espejo de la realidad (Caso, 1917c: s. p.).

Mientras Caso parece alentar los principios del realismo de finales del siglo XIX, en relación con el propósito del arte entendido como mero reflejo o expresión de la realidad, Vasconcelos propone una estética que por igual modifica al sujeto y al objeto; una moral que no abdica del perfeccionamiento espiritual del artista que se dirige a una belleza que exige esa ascética, puesto que se asocia al bien y la bondad. El neoplatonismo de Vasconcelos lo diferencia del vitalismo de Caso, pero en ambos casos la moralidad es un asunto preferente.

Son notables las palabras de Vasconcelos referidas a Plotino en El monismo estético, del que subraya su rebelión frente al aristotelismo: «El vidente Plotino descubre nuevas zonas del alma; su pensar abarca todas las cosas, pero no se inclina a catalogarlas y contarlas, y busca, más bien, la liga interior que las une. Las analogías externas no le sugieren clasificaciones; no puede escribir tratados. Pero sus escritos, fragmentarios y disímiles, expresan, sin embargo, la unidad interior del mundo; sus adivinaciones soberanas nos familiarizan con lo sobrenatural, y las Enéadas son como las once sinfonías varias de un mismo músico y mago exaltado» (Vasconcelos, 1961: 28-29). Hasta cierto punto, es imagen de la partida del Hijo Pródigo de la morada paterna y su posterior regreso. En lo que se refiere al viaje mismo, José Vasconcelos es autor, en 1916, de «El movimiento intelectual contemporáneo de México», en cuyas páginas promueve a Ulises como imagen del hombre contemporáneo. Torres Bodet, en Tiempo de arena, registra la temprana impresión que la Ilíada dejó en la sensibilidad de Vasconcelos: «Durante la juventud, le había cautivado leer a Homero. Era admirable el fervor con que describía a los soldados de la guerra de Troya poniendo las manos sobre las carnes de las bestias recién abiertas» (Torres Bodet, 1983: 481). El héroe griego es un antecedente del Hijo Pródigo dentro de la literatura mexicana. En ese artículo, Vasconcelos rehabilita la figura del héroe como expresión del hombre de letras:

Cambian las formas del infortunio, con los tiempos y con los hombres; la historia no se repite en el sentido de que produzca situaciones iguales, mas lo que sí tienen en común todas las épocas es el hado de amargura que persigue a los hombres. Si no, las aventuras, los dolores y desalientos de Ulises se repiten con variación insensible en casi toda la vida. ¡Cuando no es el mar son los hombres... el destino es el dolor y la brega! Pero lo que no a todos nos es dado es merecer la protección sagrada de Minerva, gozar el privilegio de ser útiles obreros de una gran empresa, de un poderoso ensueño que redime las penas y las convierte en escala del ideal. Para merecer esta predilección divina es necesario trasmutar la pena en noble esfuerzo y poner el espíritu en toda su humildad y en toda su potencia a disposición de la diosa, entregarle, como Ulises, la rueca de nuestros destinos (Vasconcelos, 2010: 59). 
El discurso operaba en varias direcciones: la primera, trataba de dotar de certeza a la juventud para acometer la tarea que el país necesitaba en ese momento en que se encontraba sumido en una lucha fratricida; el segundo, la confianza en un aristocratismo y elitismo en lo moral que, además de servir como ejemplo a otros jóvenes, operaba como la dote necesaria y suficiente para acometer los cambios que exigía el país: «Comprendí que Minerva gusta de que los hombres emigren y padezcan si por ese medio aumentan las relaciones mentales, y que en ese su afán, la diosa se vale de los Ulises de todas las categorías, desde los muy altos, como el personaje homérico, hasta los muy incompletos» (59). Ulises no era ya el guerrero aventurero, el viajero imprevisible, sino que actuaba con una ejemplaridad moral a la que invitaba a asumir a los jóvenes congregados a su alrededor. Ulises es el comienzo de una serie de personajes que añadirán matices y sentido a su significación, pero que culminará en el Hijo Pródigo hasta relegar al primero como personaje mitológico. Por el camino, unos y otros personajes se repartieron las simpatías de unos y otros escritores. Vasconcelos prefería a Ariel en lugar de Calibán, y también a Ulises en vez de Robinson, como asienta en De Robinson a Odiseo (Vasconcelos, 1958); mientras que la promoción siguiente, los Contemporáneos, no discriminará entre Robinson y Ulises, aunque ignora a Ariel y Calibán en contra de la doctrina vasconcelista (1503-1514). Esa afinidad con Robinson no dejaba de ser un indicio de cierta mirada crítica hacia el pensamiento vasconcelista y, por lo mismo, sugiere ya una temprana ruptura con su ideario, más explícita y tajante a partir de 1924. Hay que considerar, además, la admiración de Gide hacia la novela de Daniel Defoe, como anota en el Journal el 5 de diciembre de 1910: «J'avance dans Robinson Crusoé, pas à pas, a vec l'admiration la plus vive» (Gide, 1948: 394).

Ulises no fue una figura privativa de Vaconcelos, sino, más bien, un referente generacional, utilizado igualmente por otros integrantes del Ateneo de México. Así, Alfonso Reyes entrega a la Revista Moderna, en 1908, la narración «Una aventura de Ulises», una metáfora de la deshumanización de la ciudad moderna (Reyes, 1955). Reyes, además, asocia estos personajes con la geografía: «El simbolismo geográfico es una de las mayores fuerzas de la historia. En la literatura, él nos ha dado epopeyas y narraciones, Odiseas y libros de Simbad» (1956: 577). Simbad arraiga con fuerza en la imaginación de Reyes, opera como un principio evocador y metafórico a la hora de recrear recuerdos y vivencias: « Dolor de los libros desahuciados, que los sacan a mitad de la calle como a una familia menesterosa! Último capítulo del cuento árabe que, entre infinitas vicisitudes, nos narra las emigraciones de los libros, los viajes de Simbad de la edición princeps...» (Reyes, 1955: 368). Por su parte, Julio Torri rubrica el ensayo «Odiseo, Simbad y Róbinson» publicado por El Universal, el 4 de mayo de 1933. En este caso, se trata de un texto tardío, pero que respira la atmósfera ateneísta por todas partes que proporciona, además, la genealogía literaria de la que Ulises es precedente:

Al leer la Odisea vienen a nuestro recuerdo lecturas de la infancia, Róbinson y Simbad.

Róbinson como Odiseo pasa muchos años ausente de su patria, y lucha con una naturaleza hostil, la que acaba por cambiar en benigna. Como el rey de Ítaca, el inglés pasa largo tiempo a solas, en soledad impuesta por azares del mar, y que es muy diversa de la soledad del ermitaño, poblada toda de meditación. La soledad de estos héroes es toda acción y lucha con un mundo exterior enemigo. 
En Inglaterra, en el siglo XVII, la simpatía popular acogió a los corsarios como Drake que saqueaban puertos españoles de América, y a los marinos como el malaventurado sir Walter Rleigh, cuyas biografía abundan en hazañosos hecho.

Así nos aparece Odiseo el nauta, el descubridor, el fértil en recursos, ante los héroes de la llíada, ptoliportos o destructor de ciudades del litoral. Saqueador de puertos que, tras la sorpresa y la rapiña, distribuye con los compañeros equitativamente cautivos y riquezas de villas aún mal localizados como Crisa, Tebas de Hipoplaquia, etcétera (Torri, 2012: 192)

En todo caso, es significativa la misiva que Torri le dirige a Alfonso Reyes, el 31 de octubre de 1919, en la que escribe enigmáticamente: «¿Conoces L'enfant prodigue de André Gide? Me ha gustado mucho» (Torri, 1995: 130), el entusiasmo del autor de Fusilamientos no recibe, sin embargo, otra respuesta que la escueta: «Me hablas de tus lecturas: Conrad, Gide. Está bien» (131). También de ese año, 1918, es la carta mediante la que Torri declara a Pedro Henríquez Ureña su predilección por los ensayos de Gide recogidos en Prétextes y explica el motivo de su entusiasmo: «¿Has leído Prétextes de André Gide? Muy nietzscheano, muy sutil y francés, muy de mi gusto?» (266). Zaiteff conjetura que en 1920, una vez que Torres Bodet había publicado su antología sobre ensayos de Gide, Henríquez Ureña le preguntaba con curiosidad por el joven poeta una vez que esa antología llegó a sus manos: «¿Quién, y cómo es Jaime Torres Bodet? ¿Puede depurarse? Me interesa in potentia: por ahora es una baraúnda de citas y de ideas a medio digerir» (287). Todo indica que fue Julio Torri quien, hacia 1920, operaba como modelo y ejemplo para los miembros del Ateneo de la Juventud, el que sugirió a Jaime Torres Bodet no sólo la lectura de los ensayos de Gide, sino la antología para Cvltvra. Siendo relevante y significativo el ramillete de ensayos traducidos por Torres Bodet, más importante y decisivo para la sensibilidad de los Contemporáneos es el índice de Prétextes, en cuyas páginas se levanta todo un mapa estético y moral en donde el grupo de Xavier Villaurrutia se nutrió convenientemente.

A finales de la segunda década del siglo XX el grupo que comenzaba a sobresalir, que más tarde recibirá el nombre de Contemporáneos, intentaba abrirse un espacio en el panorama literario nacional. En unos casos, ese lugar lo ocuparán por reacción frente a la promoción anterior; en otros, reconociendo la afinidad y deuda intelectual con ella. Los personajes viajeros, compartidos por la mayoría y heredados del primer Ateneo, exhiben ya una ruptura desde el inicio entre unos y otros que no hará sino ensancharse con el paso del tiempo, nada más natural si se considera que las diferencias entre un Ateneo y otro son más significativas que las coincidencias. En parte, el fervor hacia los personajes viajeros exhibido por los Contemporáneos, aunque en cada caso con una significación diferente y personal, venía a resolver y abonar ese «raquítico medio intelectual», fórmula consignada por Jorge Cuesta en el artículo «¿Existe una crisis en nuestra literatura de vanguardia?», publicado en El Universal Ilustrado, el 14 de abril de 1932 (Cuesta, 1994a: 171). Simbad, Robinson, Jonás, Ulises, el Hijo Pródigo, etc., les permitían una fuga para la que no necesitaban trasladarse; imaginar geografías tan lejanas como desconocidas, a condición de eludir la realidad cultural de México. El viaje, primero alrededor del cuarto, y, más tarde, físico, operó como vía de escape, pero también como acicate de la curiosidad por otras culturas y literaturas. Además, el Hijo Pródigo, a partir de la lectura de la prosa de Gide resolvía cuestiones como la sexualidad de algunos integrantes de los Contemporáneos, lo que lo volvía un emblema más ajustado a sus propios intereses que Ulises. Sin embargo, Ulises no deja de 
ser una referencia en la escritura de estos, pero cada vez más opacada por la importancia que cobra el Hijo Pródigo.

\section{Bibliografía}

ABRAMS, M. H. (1992): El romanticismo: tradición y revolución. Trad. Tomás Segovia. Madrid, Visor. AligherI, Dante (2011): Divina comedia. Ed. Ángel Chiclana. México, Austral-CNCA.

Battenhouse, Roy, ed. (1955): A Companion to the Study of St. Augustine. New York, Oxford Univesity Press.

BÉNICHOU, Paul (1984): Imágenes del hombre en el clasicismo francés. Trad. Aurelio Garzón del Camino. México, FCE.

BoIX Jovaní, Alfonso (2010): «El perdón del Campeador y el retorno del Hijo Pródigo: ¿la fuente bíblica del Cantar de Mío Cid, vv. 2013-40?», Hispanic Research Journal, 2, pp. 97-102.

CAPISTRÁN, Miguel (1994): «Ulises, Simbad, Villaurrutia o la curiosidad», en Los Contemporáneos por sí mismos. México, CNCA, pp. 181-207.

CASO, Antonio (1917a): «Doctrina e ideas. La filosofía francesa contemporánea”, El Universal Ilustrado. Semanario Artístico Popular, 2 (18 de mayo de 1917), s. p.

- (1917b): «Doctrinas e ideas. Personalidad y educación», El Universal Ilustrado. Semanario Artístico Popular, 6 (25 de mayo de 1917), s. p.

- (1917c): «Doctrinas e ideas. La moralidad del arte», El Universal Ilustrado. Semanario Artístico Popular, 8, (29 de junio de 1917), s. p.

CuESTA, Jorge (1994a): «¿Existe una crisis en nuestra literatura de vanguardia?», en Miguel Capistrán, Jesús R. Martínez Malo, Víctor Peláez Cuesta y Luis Mario Schneider, eds., Obras. México, Ediciones del Equilibrista, vol. I, pp. 171-173.

- (1994b): «Montaigne y Gide», en Miguel CAPISTRÁn, Jesús R. MARTínez Malo, Víctor Peláez Cuesta y Luis Mario SchneIDER, eds., Obras. México, Ediciones del Equilibrista, vol. II, pp. 227-230.

FELl, Claude (1989): José Vasconcelos: los años del águila (1920-1925). Educación, cultura e iberoamericanismo en el México postrevolucionario. México, UNAM.

FrAZER, J. G. (1981): El folklore en el Antiguo Testamento. Trad. Gerardo Novás. México, FCE. GIDE, André (1948): Journal (1889-1912). Rio de Janeiro, Americ=Edit.

- (2002): Si la semilla no muere. (Autobiografía). Trad. Luis Echávarri. Buenos Aires, Losada.

- (2003): El regreso del Hijo Pródigo. Trad. Xavier Villaurrutia. Sevilla, Renacimiento.

- (2007): «De la influencia en literatura», en La pasión moral. (Ensayos escogidos). Trad. Glenn Gallardo. México, UNAM, pp. 17-41.

GorostizA, José (1988): «El viaje inmóvil», en Cauces de la poesía mexicana y otros textos. México, UNAM-Universidad de Colima, pp. 68-69. 
HAEGER, Barbara (1986): «The prodigal son in sixteenth and seventeenth-century Netherlandish art: depictions of the parable and the evolution of a Catholic image», Simiolus: Netherlandas Quarterly for the History of Art, 16, 2/3, pp. 128-138.

HunT, Marilyn (1982): «The Prodigal Son's Russian Roots: Avant-Garde and Icons». Danza Chronicle, 1, pp. 24-49.

ManN, Klaus (1944): André Gide y la crisis del pensamiento moderno. Trad. León Mirlas. Buenos Aires, Poseidón.

Pacheco, José Emilio (1991): «Prólogo», en André GIDE, El regreso del Hijo Pródigo. México, Fontamara, pp. 7-12.

PANABIÈRE, Louis (1983): Itinerario de una disidencia. Jorge Cuesta (1903-1942). Trad. Adolfo Castañón. México, FCE.

PAZ, Octavio (1994): Obras completas, IV. Generaciones y semblanzas. Dominio mexicano. México, FCE.

Plotino (2011): Las Enéadas (selección). Ed. José Vasconcelos. México, SEP-UNAM-FCE [Facsimilar].

REYES, Alfonso (1930): «Cuaderno de lecturas (San Ambrosio lee en voz baja)», Contemporáneos, 28-29, pp. 180-191.

(1955): «Una aventura de Ulises», en Obras completas. México, FCE, vol. I, pp. 325-334. (1956): «Inglaterra y la conciencia insular», en Obras completas. México, FCE, vol. IV, pp. 577-579.

San Agustín (2003): Confesiones. Trad. Francisco Montes de Oca. México, Porrúa.

SAGRADA BIBLIA (1955): Sagrada Biblia. Madrid, BAC.

SHERIDAN, Guillermo (1985): Los Contemporáneos ayer. México, FCE. (1999): México en 1932: la polémica nacionalista. México, FCE.

SNYDER, Susan (1966): «King Lear and the Prodigal Son», Shakespeare Quarterly, 4, pp. 361-369.

TodD, Olivier (2002): André Malraux. Una vida. Trad. Encarna Castejón. Barcelona, Tusquets.

Torres Bodet, Jaime (1983): Obras escogidas. Poesía. Autobiografía. Ensayo. México, FCE.

TORRI, Julio (1995): Epistolarios. Ed. Serge I. Zaïteff. México, UNAM.

— (2011): «Odiseo, Simbad y Róbinson», en Serge I. ZAÏTZEFF, ed., Obra completa. México, FCE, pp. 192-194.

VAsConcelos, José (1958): De Robinson a Odiseo, en Obras completas. México, Libreros Mexicanos Unidos, vol. II, pp. 1503-1514.

- (1961): El monismo estético, en Obras completas. México, Libreros Mexicanos Unidos, vol. IV, pp. 9-92.

(2010): «El movimiento intelectual contemporáneo de México», en Christopher DomínguEz MichaEL, ed. Los retornos de Ulises. Una antología de José Vasconcelos. México, FCE, pp. 5873.

Villaurrutia, Xavier (1928): «Juan Chabás y el pudor», Contemporáneos, 3, pp. 334-336. 